\title{
Petrography, magnetic susceptibility and geochemistry of the Rio Branco Granite, Carajás Province, southeast of Pará, Brazil
}

\author{
Petrografia, suscetibilidade magnética e geoquímica do Granito \\ Rio Branco, Província Carajás, sudeste do Pará, Brazil
}

\section{Patrick Araújo dos Santos ${ }^{1,2 *}$, Gilmara Regina Lima Feio ${ }^{1,3}$, Roberto Dall'Agnol ${ }^{1,2}$, Hilton Túlio Costi ${ }^{1,4}$, Claudio Nery Lamarão ${ }^{1,2}$, Marco Antonio Galarza ${ }^{5}$}

\begin{abstract}
The Paleoproterozoic Rio Branco stock intrudes the Archean Cruzadão biotite monzogranite. It occurs west of the Canaã dos Carajás city, close to the Sossego copper mine in the Carajás Province. It is constituted by undeformed and isotropic, hololeucocratic syenogranites, showing equigranular texture. The granite is formed essentially by perthitic alkali feldspar, quartz, and plagioclase, with additional variable amounts of chloritized biotite. Fluorite, allanite, and zircon are common accessory minerals, whereas pyrite and chalcopyrite are scarces. Albitization and subordinate greisenization are the main alteration processes that affected the granite. The secondary mineralogy is represented by albite, fluorite, topaz, chlorite, muscovite, siderophyllite, and iron oxides. Magnetic susceptibility values are systematically low and vary between $1.3 \times 10^{-5} \mathrm{a} 6.9 \times 10^{-4}(\mathrm{SI})$. The Rio Branco Granite is metaluminous to peraluminous and shows high $\mathrm{FeOt} /(\mathrm{FeOt}+\mathrm{MgO})$. It has geochemical affinities with ferroan, reduced A2-subtype granites. The rare earth element (REE) patterns are flat with little heavy REE fractionation and show accentuated negative Eu anomalies $\left(\mathrm{Eu} / \mathrm{Eu}^{*}=0.08-0.13\right)$. These characteristics are typical of evolved granites, derived from volatile-enriched liquids responsible by the intense subsolidus hydrothermal alteration. The dating of the Rio Branco granite did not give conclusive results, but the obtained data, associated with geological evidence, suggest that it is of Paleoproterozoic age. The comparison between the Rio Branco granite and Paleoproterozoic A-type suites of the Carajás Province suggests that the Rio Branco granite has more affinity with the Velho Guilherme suite and, in lesser degree, with the Serra dos Carajás suite. On the other hand, is clearly different from oxidized A-type granites of the Jamon suite. Despite its similarities with tin-specialized granites, the Rio Branco Granite is not associated with tin mineralizations. KEYWORDS: magnetic susceptibility; geochemistry; A-type granites; Rio Branco granite; Carajás Province.
\end{abstract}

\begin{abstract}
RESUMO: Petrografia, suscetibilidade magnética e geoquímica do Granito Rio Branco, Província Carajás, sudeste do Pará, Brazil. O Granito Rio Branco é um stock paleoproterozoico intrusivo no biotitamonzogranito arqueano Cruzadão. Ocorre a oeste da cidade de Canaã dos Carajás, nas proximidades da mina de cobre do Sossego na Provincia Carajás. É constituido por sienogranitos não deformados e isotrópicos, hololeucocráticos, em geral de granulação média. A mineralogia é formada por feldspato alcalino pertítico, quartzo e plagioclásio. A biotita, intensamente cloritizada, é a principal fase máfica, acompanhada por flluorita, allanita, zircão, pirita e calcopirita como minerais acessórios. Albitizaçấo e, com menor intensidade greisenização, afetaram o granito, sendo a mineralogia secundária albita, fluorita, topázio, clorita, muscovita, siderofilita e óxidos elou hidróxidos de ferro. O Granito Rio Branco apresenta valores sistematicamente baixos de suscetibilidade magnética (SM) variando de 1,3 $\times 10^{-5}$ a $6,96 \times 10^{4}$ (SI). Geoquimicamente, é metaluminoso a peraluminoso, possui altas razóes $\mathrm{Fe} O \mathrm{Ot}(\mathrm{FeOt}+\mathrm{MgO})$ e mostra afinidades com granitos ferrosos, tipo-A do subtipo A2. Os padróes dos ETR revelam um ligeiro enriquecimento de ETR leves em relação ao ETR pesados e anomalia negativa acentuada de $E u\left(E u / E u^{*}=0,08-0,13\right)$, resultando feição em "gaivota", característica de granitos evoluidos. O conjunto de dados obtidos demonstra o caráter evoluído do Granito Rio Branco e sua derivaçáo a partir de líquidos reduzidos e enriquecidos em voláteis, causadores das transformaçôes hidrotermais tardias. O estudo comparativo deste corpo com aqueles das suites anorogênicas da Provincia Carajás sugere que o Granito Rio Branco possui maior afinidade com os granitos das suites Velho GuiTherme e, em menor grau, Serra dos Carajás. Por outro lado, é claramente distinto da Suite Jamon. Embora apresente características similares às dos granitos especializados em estanho, não há mineralizaçōes desta natureza associadas ao corpo.
\end{abstract}

PALAVRAS-CHAVE: suscetibilidade magnética; geoquímica; granitos tipo A; Granito Rio Branco; Província Carajás.

\footnotetext{
${ }^{1}$ Group of Research on Granite Petrology , Geosciences Institute, Federal University of Pará - UFPA, Belém (PA), Brazil. E-mails: patrick.santos86@gmail.com gilmara@ufpa.br,robdal@ufpa.br, tulio@museo-goeldi.br,lamarao@ufpa.br,ari@ufpa.br

${ }^{2}$ Post-graduation Program in Geology and Geochemistry, Geosciences Institute, Federal University of Pará - UFPA, Belém (PA), Brazil.

${ }^{3}$ Geology Faculty, Marabá Campus, Federal University of Pará - UFPA, Nova Marabá (PA), Brazil.

${ }^{4}$ Emílio Goeldi Museum of Pará, Belém (PA), Brazil.

${ }^{5}$ Laboratory of Isotope Geology, Geosciences Institute, Federal University of Pará - UFPA, Belém (PA), Brazil. E-mail: antogt@ufpa,br

*Corresponding author

Manuscrito ID 25257. Recebido em: 07/12/2011. Aprovado em: 25/09/2012
} 


\section{INTRODUCTION}

A-type granites were initially described by Loiselle \& Wones (1979) as alkaline rocks formed in a rift-related or anorogenic environment, with low concentrations of $\mathrm{Al}_{2} \mathrm{O}_{3}$ and $\mathrm{CaO}$, high concentrations of elements with high ionic charges such as $\mathrm{Zr}, \mathrm{Y}, \mathrm{Nb}$ and similar, a high $\mathrm{FeOt} /(\mathrm{FeOt}+\mathrm{MgO})$ ratios, formed under a low oxygen fugacity, and with low water content. Oxidized A-type granites, however, were later described (Anderson \& Smith 1995, Anderson \& Morrison 2005, Dall'Agnol et al. 1997, 1999, Dall'Agnol \& Oliveira 2007). In the Carajás Province (CP) Paleoproterozoic A-type granites were subdivided into three suites - Jamon, Serra dos Carajás and Velho Guilherme - according to their petrographic and geochemical characteristics, metallogenetic potential, and the oxygen fugacities during their crystallization (Dall'Agnol et al. 2005). The Jamon Suite occurs in the region of the Rio Maria granite-greenstone terrane, the Velho Guilherme Suite occurs in the Xingu region, and the Serra dos Carajás Suite is distributed within various domains of the homonymous hill region, which also hosts the Rio Branco granite.

This granite occurs in the southeastern part of Pará State, west of Canaã dos Carajás town, and near the Sossego copper mine. It has characteristics similar to those of the A-type granites described by Dall'Agnol et al. (2005). Before the present study this stock was poorly described, lacking studies of petrography, geochemistry, geochronology and magnetic susceptibility. The results of these studies, reported here, allow the definition of its main characteristics, as well as an evaluation of its affinities with the three suites already mentioned. The study represents a contribution to understanding the Paleoproterozoic A-type granites of the CP.

\section{REGIONAL GEOLOGY}

The CP is located in the south-eastern part of the Amazon Craton which is composed of Archaean and Proterozoic terranes. Tassinari \& Macambira (2004) and Santos et al. (2000) believe that the Amazon Craton is divided into geochronological provinces which formed around an Archaean nucleus, elongated NW-SE and originally called the Central Amazon Province (Teixeira et al. 1989). The surrounding terranes were formed by reworking and crustal accretion in mobile belts. Souza et al. (1996) subdivided the $\mathrm{CP}$ into two different blocks, Rio Maria and Carajás, and this proposal has subsequently been fortified (Dall'Agnol et al. 2006). Various Paleoproterozoic
A-type granites intrude both Archaean blocks (Fig. 1B) (Dall'Agnol et al. 2005). These granites were attributed to three suites - Jamon, Serra dos Carajás and Velho Guilherme - according to their petrographic and geochemical characteristics as well as the oxidation state of their magmas (Dall'Agnol et al. 2005). The oxidized A-type granites intruded into Archaean rocks of the Rio Maria domain were grouped in the Jamon Suite, represented by the Jamon, Musa, Marajoara, Manda Saia, Redenção and Bannach intrusions. The moderately reduced A-type granites which intrude Archaean rocks of the Carajás Basin and the Transitional Subdomain were included in the Serra dos Carajás Suite. The Seringa granite was recently added (Paiva Jr. et al. 2011) to the Serra dos Carajás, Pojuca and Cigano granites which formed the original group. In the Xingu region the tin-bearing granites of the Velho Guilherme Suite cut the Xingu complex and intermediate to felsic volcanic rocks of the Uatumá Supergroup (Teixeira 1999, Teixeira et al. 2002). Mafic and felsic dykes, which may be related to the event which generated the Proterozoic granites, cut Archaean units and the Paleoproterozoic granites (Gastal 1987, Huhn et al. 1988, Souza et al. 1990, Silva Jr. et al. 1999, Ferreira 2009).

\section{GEOLOGY AND PETROGRAPHY OF THE RIO BRANCO GRANITE}

The Rio Branco granite is exposed in a small hill, and forms a semi-circular body with an approximate area of $31 \mathrm{~km}^{2}$. Its major, N-S axis measures $7 \mathrm{~km}$, and its minor axis is $4.5 \mathrm{~km}$. The countryside is formed by gently-sloping hills covered by dense vegetation, and has been transformed into an ecological reserve. Its contacts with country rocks are well defined in radar images (Fig. 1C), but they were not found in the field. The contrast between the geomorphological features of the granite and its surrounding rocks, and the systematic sampling undertaken contributed to the delimitation of its domains. The granite hills stand out from the local relief, and reach heights of up to $600 \mathrm{~m}$. The local relief is dominated by peneplanes or low hills. The country rocks are foliated biotite monzogranite which is wide-spread in the region (Soares 2002, Sardinha 2005, Feio et al. 2012), and has been called the Cruzadão granite (Feio et al. 2012). The Rio Branco granite is composed of isotropic granite, and crops out as pavements or metre-size blocks formed by pink rocks which are locally bleached or reddened due to albitization or greisenization, respectively. The rocks generally have homogeneous textures which are medium-grained equigranular, locally coarse - or medium to fine-grained. They are 
hololeucocratic with low modal proportions $(<5.5 \%)$ of biotite which is usually altered.

\section{Modal composition}

Table 1 presents the modal compositions in volume $\%$ obtained for samples from the granite. The QAP and $\mathrm{Q}-(\mathrm{A}+\mathrm{P})-\mathrm{M}^{\prime}$ diagrams (Fig. 2) show that all the analysed rocks are hololeucocratic syenogranite with low mafic mineral contents up to about $4.7 \%$. In this diagram the compositions of the more evolved rocks of the three A-type suites are shown form comparison.

Samples from the SW border of the Rio Branco granite have somewhat higher mafic mineral contents due to incipient greisenization, while samples from the northern part have higher contents of subsolidus albite, allowing them to be classified in some cases as partially albitized granites.

Table 1. Modal compositions of Rio Branco Granite

\begin{tabular}{|c|c|c|c|c|c|c|c|c|c|c|c|}
\hline \multicolumn{12}{|c|}{ Rio Branco Granite } \\
\hline \multirow{2}{*}{ Mineralogy } & ARC & ARC & ARC & ARC & ARC & ARC & ARC & ARC & ARC & ARC & ARC \\
\hline & $123^{1}$ & $125^{1}$ & $130^{1}$ & $137^{2}$ & $133^{1}$ & $82^{1}$ & 91 & $135^{1,2}$ & $136^{1}$ & $138^{3}$ & $139^{3}$ \\
\hline Rock & \multirow{2}{*}{ SGM } & \multirow{2}{*}{ SGM } & \multirow{2}{*}{ SGM } & \multirow{2}{*}{ SGM } & \multirow{2}{*}{ SGMF } & \multirow{2}{*}{$\begin{array}{l}\text { Albitized } \\
\text { SGM }\end{array}$} & \multirow{2}{*}{$\begin{array}{l}\text { Albitized } \\
\text { SGM }\end{array}$} & \multirow{2}{*}{$\begin{array}{l}\text { Albitized } \\
\text { SGM }\end{array}$} & \multirow{2}{*}{$\begin{array}{l}\text { Albitized } \\
\text { SGM }\end{array}$} & \multirow{2}{*}{$\begin{array}{l}\text { Greisenized } \\
\text { SGM }\end{array}$} & \multirow{2}{*}{$\begin{array}{l}\text { Greisenized } \\
\text { SGM }\end{array}$} \\
\hline Grain size & & & & & & & & & & & \\
\hline Albite + perthite & 46.6 & 46 & 46.9 & 42 & 45.8 & 49.8 & 58.6 & 48.1 & 61.9 & 53.1 & 48.4 \\
\hline Quartz & 34.9 & 39.6 & 32.2 & 38.8 & 37 & 33 & 28.8 & 30 & 25 & 23.6 & 35.9 \\
\hline Plagioclase & 17 & 11.8 & 17 & 16.6 & 14.7 & 14.6 & 12.4 & 19.6 & 12.1 & 18.8 & 10 \\
\hline Biotite+ chlorite & 0.1 & 1.8 & 2.7 & 2.3 & 1.8 & 1 & - & 2.1 & 0.1 & 3 & 4.7 \\
\hline Fluorite & 0.6 & 0.6 & 1 & 0.2 & 0.4 & 0.8 & - & - & - & 0.8 & 0.8 \\
\hline Allanite & 0.4 & $\operatorname{Tr}$ & $\operatorname{Tr}$ & $\operatorname{Tr}$ & $\operatorname{Tr}$ & $\operatorname{Tr}$ & $\operatorname{Tr}$ & $\operatorname{Tr}$ & $\operatorname{Tr}$ & $\operatorname{Tr}$ & $\operatorname{Tr}$ \\
\hline Zircon & $\operatorname{Tr}$ & $\operatorname{Tr}$ & $\operatorname{Tr}$ & $\operatorname{Tr}$ & $\operatorname{Tr}$ & $\operatorname{Tr}$ & $\operatorname{Tr}$ & $\operatorname{Tr}$ & $\operatorname{Tr}$ & $\operatorname{Tr}$ & $\operatorname{Tr}$ \\
\hline Iron oxide/hydroxide & $\operatorname{Tr}$ & $\operatorname{Tr}$ & $\operatorname{Tr}$ & $\operatorname{Tr}$ & $\operatorname{Tr}$ & $\operatorname{Tr}$ & $\operatorname{Tr}$ & $\operatorname{Tr}$ & $\operatorname{Tr}$ & $\operatorname{Tr}$ & $\operatorname{Tr}$ \\
\hline Muscovite & $\operatorname{Tr}$ & $\operatorname{Tr}$ & $\operatorname{Tr}$ & 0.1 & 0.3 & $\operatorname{Tr}$ & $\operatorname{Tr}$ & 0.2 & $\operatorname{Tr}$ & $\operatorname{Tr}$ & $\operatorname{Tr}$ \\
\hline$\Sigma$ Mafic $=\mathrm{M}^{\prime}$ & 0.5 & 1.8 & 2.7 & 2.4 & 2.1 & 1 & $\operatorname{Tr}$ & 2.3 & 0.1 & 3 & 4.7 \\
\hline
\end{tabular}

SGM: Medium-grained syenogranite; SGMF: Medium to fine-grained syenogranite; ${ }^{1}$ Completely oxidized and chloritized biotite; ${ }^{2}$ Granite with topaz and albite; ${ }^{3}$ Granite with topaz, siderophyllite, chlorite and fluorite

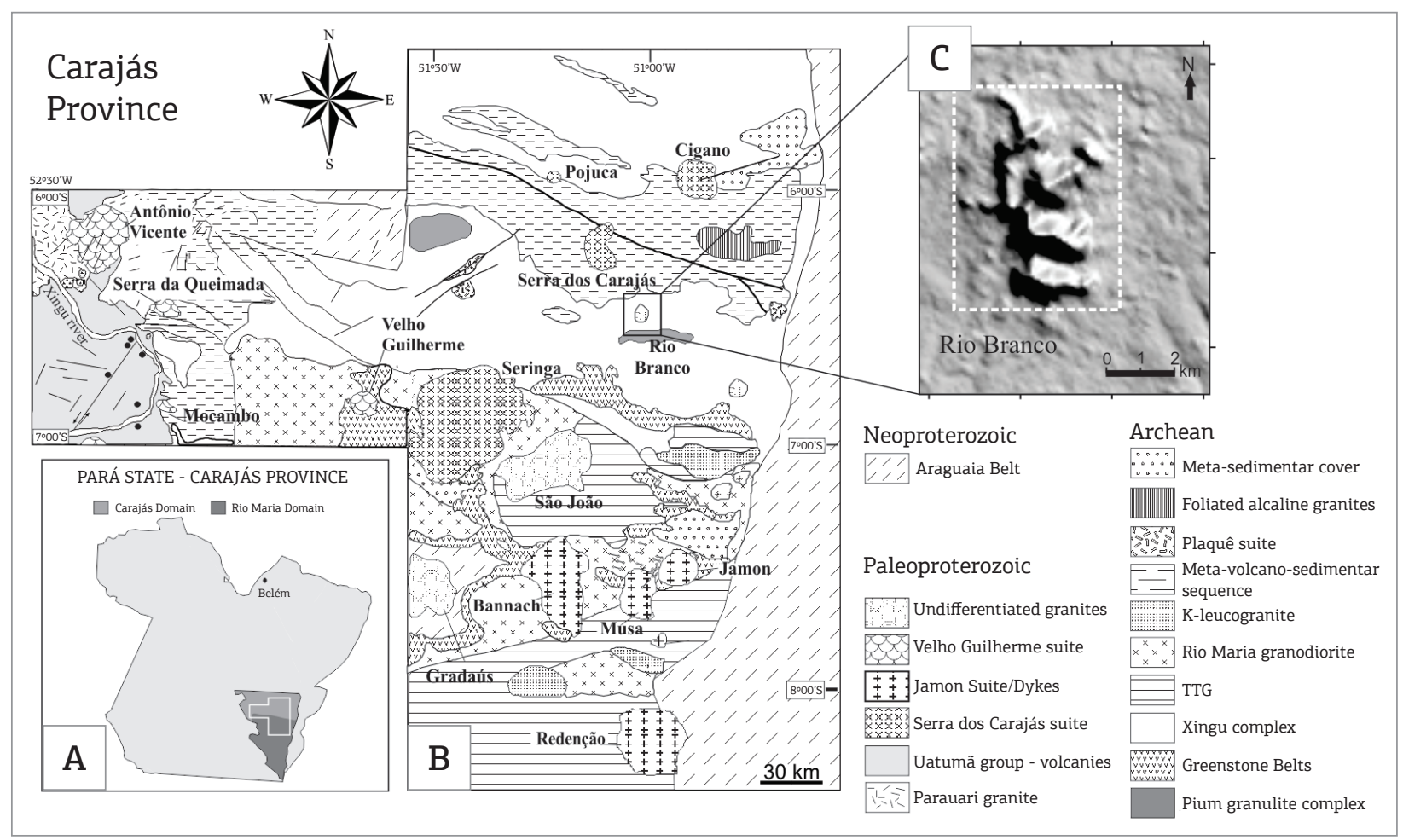

Figure 1. (A) Map of Pará State with emphasis on the tectonic of Carajás and the Rio Maria domains within the Carajás Province (after Vasquez et al. 2008); (B) simplified geological map of the Carajás Province, showing the anorogenic suites and the Rio Branco Granite (after Dall 'Agnoll et al. 2005); (C) radar image of the Rio Branco granite. 


\section{Syenogranite}

This is the dominant variety, and has a medium-grained, equigranular hypidiomorphic texture with variation to coarse - or fine-grained. It is essentially composed of perthitic alkali feldspar, quartz and plagioclase (Fig. 3A). Chloritized biotite is the main mafic mineral, and the accessory minerals include fluorite1, allanite, zircon and opaque minerals. The alkali feldspar has modified exsolution textures (Smith \& Brown 1988), mainly represented by vein perthite. Granophyric intergrowths of alkali feldspar and quartz are also common (Fig. 3B).

\section{Greisenized syenogranite}

The rocks are massive, pink with reddish tones which reflect the effects of the hydrothermal alteration. Textures are fundamentally similar to those of the dominant syenogranite. The post magmatic transformations, results of the greisenization, are shown by the presence of secondary minerals such as topaz (Figs. 3C and D), fluorite2, muscovite and siderophyllite. Most of these minerals occur as anhedral to subhedral crystals which substitute plagioclase. Siderophyllite, and in some cases fluorite2, may also be found in mafic aggregates.

Analyses by scanning electron microscopy identified Ce-fluorcerite, xenotime, and rare earth element minerals, all very fine-grained and of local occurrence.

\section{Albitized syenogranite}

This rock is bleached but its textures are similar to those of other petrographic varieties. It lacks mafic minerals and has important modal proportions of albite. This occurs in a number of forms, the most common of which is as exsolution lamellae inside alkali feldspar which are then modified

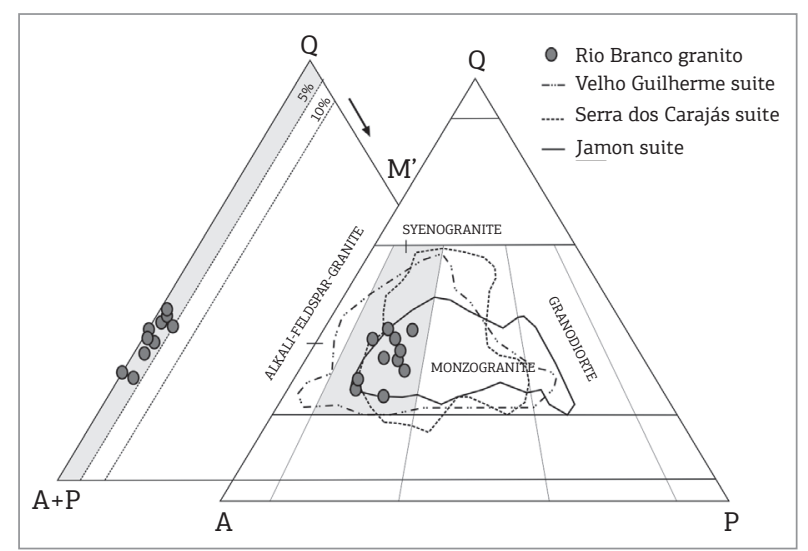

Figure 2. Q-A-P (fields according to Streckeisen 1976) and $\mathrm{Q}-(\mathrm{A}+\mathrm{P})-\mathrm{M}^{\prime}$ modal diagrams for the studied rocks. A: potash feldspar + albite; $\mathbf{M}^{\prime}: \Sigma$ (biotite + zircon + iron hydroxide + allanite + chlorite). Data for the Jamon, Serra dos Carajás and Velho Guilherme suites after Dall'Agnoll et al. (2005). to form vein perthite (Smith \& Brown 1988). In more intensely albitized rocks intergranular albite is present in textural varieties containing inverted coronas and as fingers (Fig. 3F; Ramberg 1962, Smith 1974, Dall'Agnol et al. 1993), as well as chess board albite (Fig. 3E; Smith 1974). These types represent products of substitution of alkali feldspar, and the alteration is stronger in the NE part of the body.

\section{MAGNETIC PETROLOGY}

\section{Iron-titanium oxide minerals}

The iron-titanium minerals identified in the Rio Branco granite are mainly hematite with very rare crystals of magnetite (Figs. 3G and H). Hematite normally occurs as inclusions in, or associated with chloritized biotite, or as thin films interstitial to feldspars. In the former occurrence hematite occurs as fine-grained, elongated crystals along the cleavage planes of chlorite (Fig. 3G). This type is common where the primary biotite was intensely chloritized and oxidized. Magnetite was found in a single sample (ARC-137) which has the highest magnetic susceptibility (MS) found in the granite. It occurs as rare, small subhedral to euhedral crystals which show signs of oxidation (Fig. 3H). The parcial replacement of magnetite by martite (hematite) is evident. Martite occurs in irregular masses at the borders of the host magnetite.

\section{Magnetic susceptibility}

The Rio Branco granite has MS values in the range between $1.3 \times 10^{-5}$ and $6.96 \times 10^{-4} \mathrm{SI}$, with a mean value of $1.55 \times 10^{-4}$ SI. Data and statistics are given in Tab. 2 . Log SI values are between -4.88 and -3.15 with a concentration between -4.69 and -3.81 . The statistical analysis is not very robust due to relatively small number of samples. The frequency histogram seems to be bimodal, but it is not possible to exclude a single mode. A normal probability graph, not shown here, was also drawn, and also suggested a single mode, but its interpretation was inconclusive.

The MS values are systematically very low, and this fact, allied to the information obtained from the studies of the Fe-Ti minerals, show that the rocks found at the present erosion level must have formed under reducing conditions. The alternative explanation that the rocks were formed under oxidizing conditions, but that subsolidus reactions destabilized magnetite, finds no support from textural features. In the only sample in which magnetite was found it is only slightly altered (Fig. $8 \mathrm{H}$ ). 

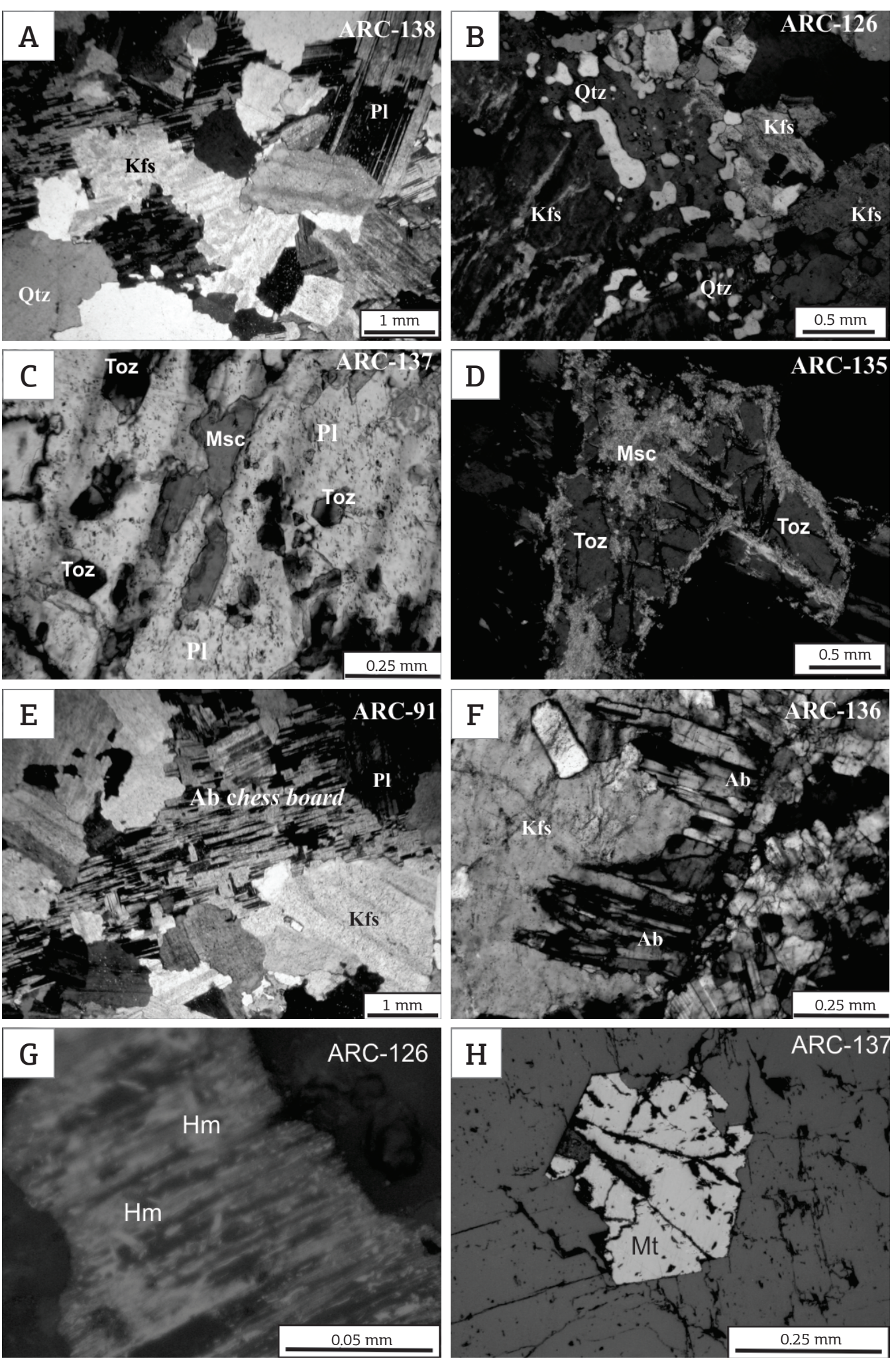

Figure 3. Textures of the Rio Branco granite. (A) Equigranular hypidiomorphic texture; (B) Granophyric embryos; (C and D) Hydrothermal association of topaz and muscovite substituting plagioclase; (E) Chess-board albite; (F) Albite fingers replacing perthite; $(G)$ Hematite crystals along cleavage planes in chloritized biotite; $(\mathrm{H})$ Subhedral crystal of magnetite undergoing incipient martitization. Abbreviations of mineral names follow Kretz (1983). Photomicrographs A to F were taken in transmitted light, A and F with crossed nicols. Photomicrographs $\mathrm{G}$ and $\mathrm{H}$ were obtained in reflected light with crossed nicols. 


\section{GEOCHEMISTRY}

The chemical analyses for major elements and trace elements, including the REE (rare earth elements), were performed by ICP-ES and ICP-MS, respectively, at the ACME Analytical Laboratories Ltd. In Canada. The chemical compositions of the Rio Branco granite are given in Table 3 together with representative analyses of the most evolved facies of the anorogenic granites of the CP.

The granite is composed of silica-rich rocks $\left(73.84 \%<\mathrm{SiO}_{2}<77.71 \%\right)$, with low concentrations of $\mathrm{TiO}_{2}, \mathrm{Al}_{2} \mathrm{O}_{3}, \mathrm{CaO}, \mathrm{MgO}$ and $\mathrm{P}_{2} \mathrm{O}_{5}$. The samples have low concentrations of $\mathrm{Sr}$ and $\mathrm{Ba}$, moderate concentrations of $\mathrm{Zr}$ and $\mathrm{Hf}$, and systematically high concentrations of $\mathrm{Rb}$, $\mathrm{Y}$, Th, U, Nb and Ga. In general the compositions of the samples are relatively uniform except for those samples which passed through post-magmatic transformations.

The dominant syenogranites are metaluminous to peraluminous (Fig. 5A), and show affinities with intraplate granite (Fig. 5B), and with rocks of the $\mathrm{A} 2$ subgroup of A-type granites (Figs. $5 \mathrm{C}$ and $\mathrm{D}$ ). $\mathrm{K}_{2} \mathrm{O} / \mathrm{Na}_{2} \mathrm{O}$ ratios are above 1.0 (Table 3), and $\mathrm{FeOt} /(\mathrm{FeOt}+\mathrm{MgO}$ ) ratios are very high $(>0.95)$. In the $\mathrm{FeOt} /(\mathrm{FeOt}+\mathrm{MgO})$ versus $\mathrm{SiO}_{2}$ diagram (Fig. 5E, Frost et al. 2001) the compositions plot in the field of ferroan A-type granites, and the reduced character is revealed using the $\mathrm{FeOt} /(\mathrm{FeOt}+\mathrm{MgO})$ vs. $\mathrm{Al}_{2} \mathrm{O}_{3}$ diagram (Fig. 5F; fields according to Dall'Agnol \& Oliveira 2007).

Table 2. Magnetic susceptibility data and statistics for the Rio Branco Granite

\begin{tabular}{l|c|c}
\hline \multicolumn{3}{|c}{ Rio Branco Granite } \\
\hline Sample & K(SI) & Log (K)SI \\
\hline ARC-137 & $6.9 \times 10^{-4}$ & -3.15697 \\
\hline ARC-138 & $5.7 \times 10^{-4}$ & -3.24413 \\
\hline ARC-132A & $1.5 \times 10^{-4}$ & -3.81436 \\
\hline ARC-126 & $1.4 \times 10^{-4}$ & -3.83367 \\
\hline ARC-139 & $1.0 \times 10^{-4}$ & -3.98576 \\
\hline ARC-133 & $9.3 \times 10^{-5}$ & -4.03152 \\
\hline ARC-140 & $8.6 \times 10^{-5}$ & -4.06550 \\
\hline ARC-130 & $4.6 \times 10^{-5}$ & -4.33724 \\
\hline ARC-136 & $4.3 \times 10^{-5}$ & -4.36653 \\
\hline ARC-123 & $3.3 \times 10^{-5}$ & -4.48149 \\
\hline ARC-135 & $2.0 \times 10^{-5}$ & -4.69897 \\
\hline ARC-125 & $2.0 \times 10^{-5}$ & -4.69897 \\
\hline ARC-91 & $1.3 \times 10^{-5}$ & -4.88606 \\
\hline \multicolumn{3}{|c|}{ Statistics } \\
\hline Mean & $1.55 \times 10^{-4}$ & - \\
\hline Geometric mean & $7.53 \times 10^{-5}$ & - \\
\hline Variance & $4.77 \times 10^{-8}$ & - \\
\hline Standard deviation & $2.18 \times 10^{-4}$ & - \\
\hline Minimum value & $1.30 \times 10^{-5}$ & - \\
\hline Maximum value & $6.96 \times 10^{-4}$ & - \\
\hline & & - \\
\hline
\end{tabular}

As far as the lithophile elements are concerned, as a result of the low concentrations of $\mathrm{Sr}$ and $\mathrm{Ba}$, and the high concentration of $\mathrm{Rb}$, ratios such as $\mathrm{Rb} / \mathrm{Sr}$ and $\mathrm{Rb} / \mathrm{Ba}$ are always large.

The geochemical characteristics and signatures of the Rio Branco granite samples are consistent with those found for the Paleoproterozoic anorogenic suites of the CP (Dall'Agnol et al. 2005).

In the albitized syenogranite, concentrations of $\mathrm{TiO}_{2}$, FeOt, $\mathrm{CaO}$ and $\mathrm{K}_{2} \mathrm{O}$ are diminished, while $\mathrm{Al}_{2} \mathrm{O}_{3}$ is somewhat enriched, and $\mathrm{Na}_{2} \mathrm{O}$, more so in comparison with the unmodified rocks. Contents of $\mathrm{Ba}, \mathrm{Rb}, \mathrm{Zr}, \mathrm{Y}$ and $\mathrm{Nb}$ are also reduced by albitization. The intensely albitized sample ARC-91 has extremely low $\mathrm{K}_{2} \mathrm{O} / \mathrm{Na}_{2} \mathrm{O}, \mathrm{Rb} / \mathrm{Sr}$ and $\mathrm{Rb} / \mathrm{Ba}$ ratios (Table 3), while sample ARC-135 which presents petrographic evidence for incipient albitization does not have an unusually low $\mathrm{K}_{2} \mathrm{O} / \mathrm{Na}_{2} \mathrm{O}$ ratio or a diminished $\mathrm{Rb}$ concentration, but shows other geochemical evidences for albitization, such as lower concentrations of $\mathrm{Zr}, \mathrm{Nb}$ and $\mathrm{Y}$.

The geochemical composition of the greisenized granite is generally similar to that of the unmodified granites, and the greisenization was clearly incipient, insufficient to cause expressive mobilization of the chemical elements.

REE patterns show a very accentuated negative Eu anomalies $\left(\mathrm{Eu} / \mathrm{Eu}^{*}=0.045-0.229\right.$, Tab. 3), and slight relative enrichment of the heavy $\operatorname{REE}\left(\mathrm{La}_{\mathrm{N}} / \mathrm{Lu}_{\mathrm{N}}=1.039\right.$ 5.826) resulting in the gull-wing patterns which are typical of highly evolved granites, and of F and Sn-bearing granitic magmas (Haapala 1997, Taylor \& Fryer 1983, Dall'Agnol et al. 1993). The pattern of the strongly albitized (sample ARC-91) is similar but less-rich in REE, showing that the fluids which caused albitization were also capable of leaching REE, while the pattern of the slightly greisenized sample is very similar to those of the unaltered samples, showing that the incipient greisenization did not mobilize the REE.

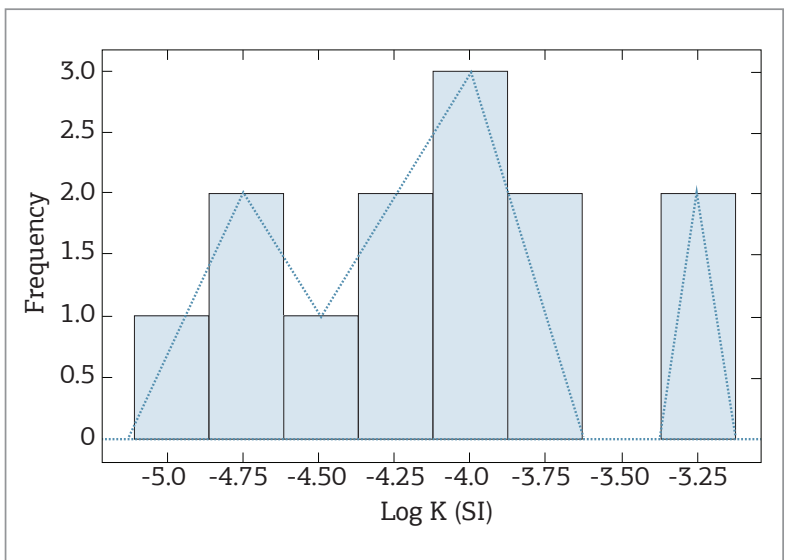

Figure 4. Histogram of magnetic susceptibility data for samples from the Rio Branco granite. 


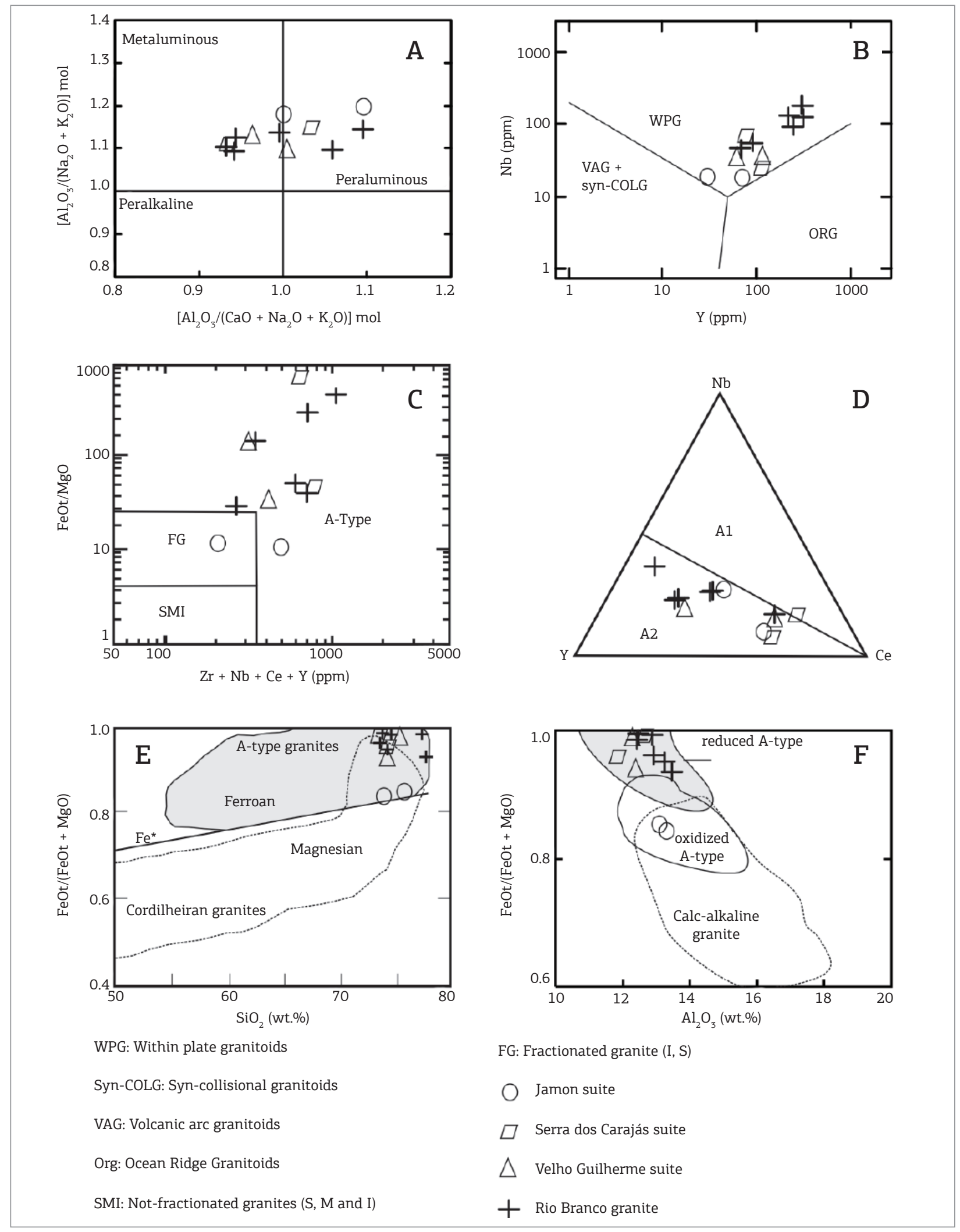

Figure 5. (A) A/CNK vs A/NK (molecular proportions; Shand 1950) showing the metaluminous character of the Rio Branco granite, which becomes peraluminous when affected by albitization; (B) discrimination of tectonic environment (Pearce et al. 1984); (C) diagram identifying A-type granitoids (Whalen et al. 1987); (D) Nb - Y - Ce diagram (Eby 1992) showing the distribution of analyses of the Rio Branco granite; (E) FeOt/(FeOt + MgO) vs. SiO after Frost et al. (2001) demonstrating that the Rio Brando granite samples are ferroan A-type; (F) FeOt/(FeOt $+\mathrm{MgO}$ ) vs. $\mathrm{Al}_{2} \mathrm{O}_{3}$ diagram with fields defined by Dall'Agnol and Oliveira (2007), demonstrating the reduced nature of the Rio Branco granite. 
Table 3. Chemical composition of the Rio Branco Granite and representative samples of evolved facies of the anorogenic suite of the Carajás province (data from Dall'Agnol et al. 2005)

\begin{tabular}{|c|c|c|c|c|c|c|c|c|c|c|c|c|}
\hline \multirow{3}{*}{$\begin{array}{l}\text { Granite } \\
\text { Suite } \\
\text { Facies }\end{array}$} & \multirow{2}{*}{\multicolumn{6}{|c|}{ Rio Branco Granite }} & \multirow{2}{*}{\multicolumn{2}{|c|}{$\begin{array}{l}\text { Jamon suite } \\
\text { Redenção }\end{array}$}} & \multirow{2}{*}{\multicolumn{2}{|c|}{$\begin{array}{c}\text { Serra dos } \\
\text { Carajás suite } \\
\begin{array}{c}\text { Serra dos } \\
\text { Carajás }\end{array}\end{array}$}} & \multicolumn{2}{|c|}{ Velho Guilherme suite } \\
\hline & & & & & & & & & & & \multirow{2}{*}{$\begin{array}{c}\text { Antônio } \\
\text { Vicente }\end{array}$} & \multirow{2}{*}{$\begin{array}{c}\begin{array}{c}\text { Velho } \\
\text { Guilherme }\end{array} \\
\text { BSG }\end{array}$} \\
\hline & BSG & BSG & BSG & BSGA & BSGA & BSGG & BMzG & LMzG & BSG & BSG & & \\
\hline Samples & $\begin{array}{c}\text { ARC- } \\
130\end{array}$ & $\begin{array}{l}\text { ARC- } \\
123\end{array}$ & $\begin{array}{l}\text { ARC- } \\
137\end{array}$ & $\begin{array}{l}\text { ARC- } \\
135\end{array}$ & $\begin{array}{c}\text { ARC- } \\
91\end{array}$ & $\begin{array}{l}\text { ARC- } \\
139\end{array}$ & $\begin{array}{l}\text { JCR- } \\
\text { O1D }\end{array}$ & $\begin{array}{c}\text { DCR- } \\
07\end{array}$ & $\begin{array}{l}\text { CJ- } \\
29 B\end{array}$ & $\begin{array}{l}\text { CJ- } \\
32 B\end{array}$ & SL-3A & NN-VG32 \\
\hline $\mathrm{SiO}_{2}$ (wt.\%) & 73.84 & 74.29 & 74.34 & 77.50 & 77.71 & 73.90 & 74.20 & 76.00 & 73.89 & 74.50 & 74.40 & 75.67 \\
\hline $\mathrm{TiO}_{2}$ & 0.09 & 0.05 & 0.08 & 0.02 & 0.02 & 0.05 & 0.30 & 0.12 & 0.16 & 0.20 & 0.17 & 0.05 \\
\hline $\mathrm{Al}_{2} \mathrm{O}_{3}$ & 12.93 & 13.25 & 12.47 & 12.43 & 13.47 & 12.87 & 13.30 & 13.10 & 12.68 & 11.85 & 12.42 & 12.29 \\
\hline $\mathrm{Fe}_{2} \mathrm{O}_{3}$ & 1.67 & 0.66 & 2.38 & 0.77 & 0.16 & 1.54 & 1.31 & 0.65 & 1.10 & 1.03 & $2.25^{*}$ & $1.39^{*}$ \\
\hline $\mathrm{FeO}$ & 1.50 & 0.59 & 2.14 & 0.69 & 0.14 & 1.38 & 0.62 & 0.31 & 1.34 & 1.92 & nd & nd \\
\hline $\mathrm{MnO}$ & 0.02 & 0.02 & 0.01 & $<0.01$ & $<0.01$ & 0.01 & 0.05 & 0.03 & nd & 0.01 & 0.02 & 0.01 \\
\hline $\mathrm{MgO}$ & 0.06 & 0.03 & $<0.01$ & $<0.01$ & $<0.01$ & $<0.01$ & 0.22 & $<0.10$ & 0.03 & 0.04 & 0.14 & 0.02 \\
\hline $\mathrm{CaO}$ & 1.21 & 1.21 & 0.85 & 0.26 & 0.23 & 1.03 & 1.10 & 0.55 & 0.68 & 1.11 & 1.02 & 0.58 \\
\hline $\mathrm{Na}_{2} \mathrm{O}$ & 3.46 & 3.54 & 3.48 & 3.65 & 7.36 & 3.43 & 3.50 & 3.10 & 2.74 & 2.82 & 3.29 & 3.79 \\
\hline $\mathrm{K}_{2} \mathrm{O}$ & 5.37 & 5.72 & 4.85 & 4.50 & 0.18 & 5.68 & 5.10 & 5.40 & 6.03 & 5.57 & 5.22 & 4.57 \\
\hline $\mathrm{P}_{2} \mathrm{O}_{5}$ & $<0.01$ & 0.01 & 0.03 & 0.01 & 0.02 & 0.03 & 0.05 & 0.01 & 0.13 & 0.14 & 0.12 & 0.01 \\
\hline LOI & 1.2 & 1.0 & 1.3 & 0.8 & 0.8 & 1.3 & 0.31 & 0.17 & 0.55 & 0.22 & 0.86 & 0.71 \\
\hline Total & 98.65 & 98.78 & 98.99 & 99.14 & 99.15 & 98.54 & 100.1 & 99.44 & 99.33 & 99.41 & 99.91 & 99.09 \\
\hline $\mathrm{Ba}$ (ppm) & 227 & 443 & 90 & 145 & 37 & 103 & 909 & 32 & nd & nd & 386 & 20 \\
\hline $\mathrm{Rb}$ & 278 & 226 & 443 & 358 & 11 & 352 & 204 & 396 & 243 & 253 & 339 & 533 \\
\hline $\mathrm{Sr}$ & 27.1 & 52.6 & 10.9 & 8.9 & 33.5 & 11.8 & 196 & 27 & 69 & 62 & 51 & 9 \\
\hline $\mathrm{Zr}$ & 163 & 174 & 301 & 58 & 107 & 137 & 258 & 126 & 244 & 301 & 163 & 106 \\
\hline $\mathrm{Hf}$ & 9.4 & 11.5 & 17 & 4.6 & 9.6 & 8.8 & nd & nd & nd & nd & nd & nd \\
\hline $\mathrm{Nb}$ & 94 & 129 & 182 & 46 & 55 & 123 & 21 & 21 & 28 & 75 & 34 & 37 \\
\hline $\mathrm{Y}$ & 244 & 220 & 308 & 68 & 91 & 315 & 71 & 30 & 115 & 78 & 63 & 114 \\
\hline $\mathrm{Ga}$ & 31 & 24 & 36 & 34 & 31 & 31 & 23 & 27 & nd & nd & $<5$ & 29 \\
\hline Th & 103 & 74 & 150 & 38 & 49 & 91 & $<5$ & $<5$ & nd & nd & 56 & 48 \\
\hline $\mathrm{U}$ & 32 & 16 & 34 & 18 & 25 & 29 & $<10$ & $<10$ & nd & nd & 30 & 12 \\
\hline Sn & 2 & $<1$ & 6 & 2 & $<1$ & 2 & nd & nd & nd & nd & nd & nd \\
\hline $\mathrm{Cu}$ & 16.2 & 14.7 & 3.9 & 41.7 & 4.8 & 7.7 & nd & nd & nd & nd & 9 & nd \\
\hline $\mathrm{Zn}$ & 16 & 17 & 19 & 7 & 7 & 12 & nd & nd & nd & nd & 24 & 27 \\
\hline $\mathrm{La}$ & 45.5 & 172.8 & 110.9 & 44.1 & 20.2 & 61.0 & 71.8 & 11.9 & 268 & 160 & 80.90 & 26.38 \\
\hline $\mathrm{Ce}$ & 104.9 & 183.0 & 261.3 & 176.9 & 16.9 & 138.6 & 139.7 & 31.9 & 259 & 331 & 157.80 & 61.58 \\
\hline $\mathrm{Nd}$ & 61.4 & 178.7 & 115.0 & 38.1 & 20.4 & 85.6 & 51.7 & 9.2 & 168 & 107 & 49.4 & 32.31 \\
\hline $\mathrm{Sm}$ & 18.35 & 43.15 & 28.36 & 9.50 & 6.30 & 25.84 & 9.3 & 1.8 & 27 & 16.5 & 10.7 & 9.13 \\
\hline $\mathrm{Eu}$ & 0.66 & 3.22 & 0.43 & 0.16 & 0.59 & 0.49 & 1.4 & 0.2 & 2.33 & 1.24 & 0.7 & 0.10 \\
\hline $\mathrm{Gd}$ & 23.37 & 43.32 & 30.81 & 8.32 & 8.46 & 31.93 & 7.6 & 1.3 & 18.9 & 11.1 & 8.7 & 10.49 \\
\hline Dy & 29.45 & 40.50 & 37.70 & 13.60 & 14.42 & 39.42 & 5.0 & 0.8 & 17.2 & 8.91 & 9.8 & 14.35 \\
\hline $\mathrm{Er}$ & 20.09 & 23.26 & 26.45 & 11.36 & 11.52 & 27.05 & 3.6 & 0.4 & 9.78 & 4.82 & 6.3 & 10.69 \\
\hline $\mathrm{Yb}$ & 20.78 & 21.24 & 26.14 & 17.09 & 12.69 & 26.59 & 2.8 & 0.4 & 8.44 & 4.05 & 7.6 & 11.56 \\
\hline $\mathrm{Lu}$ & 3.10 & 2.87 & 3.80 & 2.56 & 1.88 & 3.86 & 0.4 & 0.1 & 1.06 & 0.56 & 1.0 & 1.79 \\
\hline $\begin{array}{l}\mathrm{FeOt} /(\mathrm{FeOt} \\
+\mathrm{MgO})\end{array}$ & 0.96 & 0.95 & 0.99 & 0.98 & 0.93 & 0.99 & 0.90 & 0.92 & 0.98 & 0.98 & 0.94 & 0.98 \\
\hline $\mathrm{K}_{2} \mathrm{O} / \mathrm{Na}_{2} \mathrm{O}$ & 1.55 & 1.61 & 1.39 & 1.23 & 0.024 & 1.65 & 1.46 & 1.74 & 2.20 & 1.98 & 1.59 & 1.22 \\
\hline $\mathrm{Eu} / \mathrm{Eu}^{*}$ & 0.10 & 0.23 & 0.04 & 0.05 & 0.25 & 0.05 & 0.49 & 0.29 & 0.30 & 0.26 & 0.21 & 0.03 \\
\hline$(\mathrm{La} / \mathrm{Lu}) \mathrm{N}$ & 5.82 & 1.04 & 1.67 & 1.42 & 10.33 & 2.82 & 18.63 & 12.37 & 25.90 & 28.57 & 8.09 & 1.47 \\
\hline
\end{tabular}

LOI: loss on ignition; nd: not determined; $\mathrm{Fe}_{2} \mathrm{O}_{3}$ is total; A: Albitized; G: Greisenized; B: Biotite; MzG: Monzogranite; SG: Syenogranite; L: Leuco. 


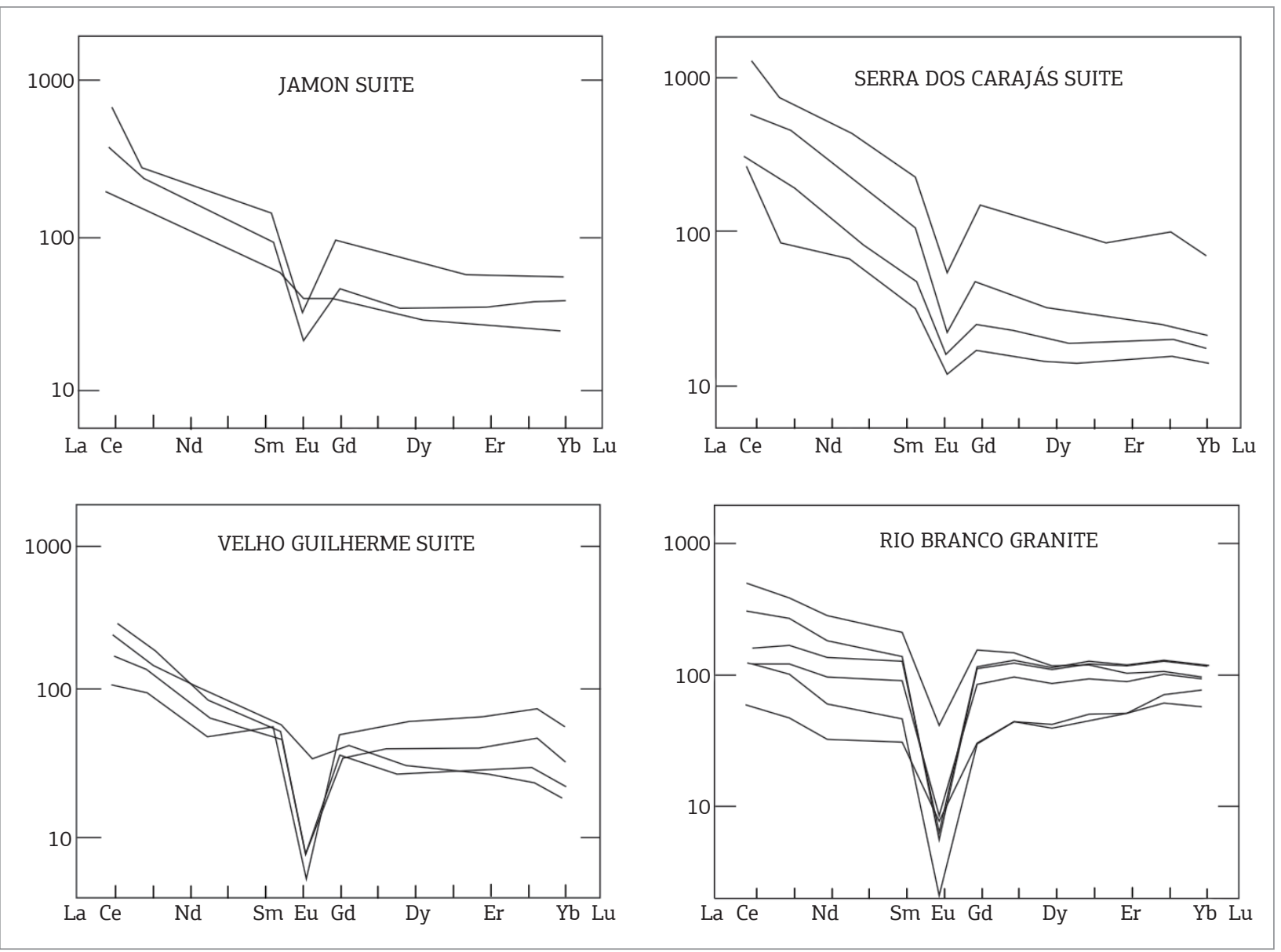

Figure 6. Rare earth element patterns normalised to chondrite (Evensen et al. 1978) for representative samples of the Rio Branco granite, compared to patterns for different facies of the Jamon, Serra dos Carajás and Velho Guilherme Suites (Dall'Agnol et al. 2005).

\section{GEOCHRONOLOGY}

The isotopic analyses of the Rio Branco granite were performed at the Geochronology Laboratory (Pará-Iso) of the Federal University of Pará (GI-UFPA). The Pb-evaporation method on zircon by thermo-ionization was used. The procedures developed by Kober $(1986,1987)$ were adapted for use at Pará-Iso by por Gaudette et al. (1998).

Zircon concentrates were extracted from ca. $10 \mathrm{~kg}$ rock samples using conventional gravimetric methods of heavy mineral separation and magnetic (Frantz isodynamic separator) techniques. The analyses were made using a Finnigan MAT-262 mass spectrometer. The $\mathrm{Pb}$ is extracted by heating in three evaporation steps at 1450,1500 , and $1550^{\circ} \mathrm{C}$ and loaded on an ionization filament.

Ages were determined for each of these stages. The age accepted for each sample was taken to be the mean of the most coherent ages obtained at the higher temperatures. Corrections for the presence of common $\mathrm{Pb}\left({ }^{204} \mathrm{~Pb}\right)$ used the model proposed by Stacey and Kramers (1975).
The biotite syenogranite (sample ARC-137) contained two morphological types of zircon: (1) euhedral to subhedral brown crystals; and (2) light caramel-colored subhedral, sometimes rounded crystals. In general the crystals are fractured with sieve structures, and contain dark (in transmitted light) inclusions which, using a scanning electron microscope (see later), yield very bright back scattered electron images. Semi-quantitative energy dispersive spectrometric analysis shows that these inclusions contain about 29\% Th, suggesting that they are composed of thorianite (Figs. 7A and B). Some of the crystals are short prisms with abraded edges and internal zoning (Fig. 7C).

24 grains selected for analysis and only 7 produced sufficiently stable $\mathrm{Pb}$ beams (Tab. 4). Of these, the results for grains 1, 3, 4 and 9 were discarded from the age calculation because they yielded high commom $\mathrm{Pb}\left({ }^{204} \mathrm{~Pb} /{ }^{206} \mathrm{~Pb}>0.0004\right)$. Grain $\mathrm{n}^{\mathrm{o}} 7$ yielded an age of $1697 \mathrm{Ma}$, but with a very large error of $183 \mathrm{Ma}$, and was also excluded from the age calculation. This left grains 2 and 5 with ages of $1909 \pm 7 \mathrm{Ma}$, and $1894 \pm 16 \mathrm{Ma}$ for 

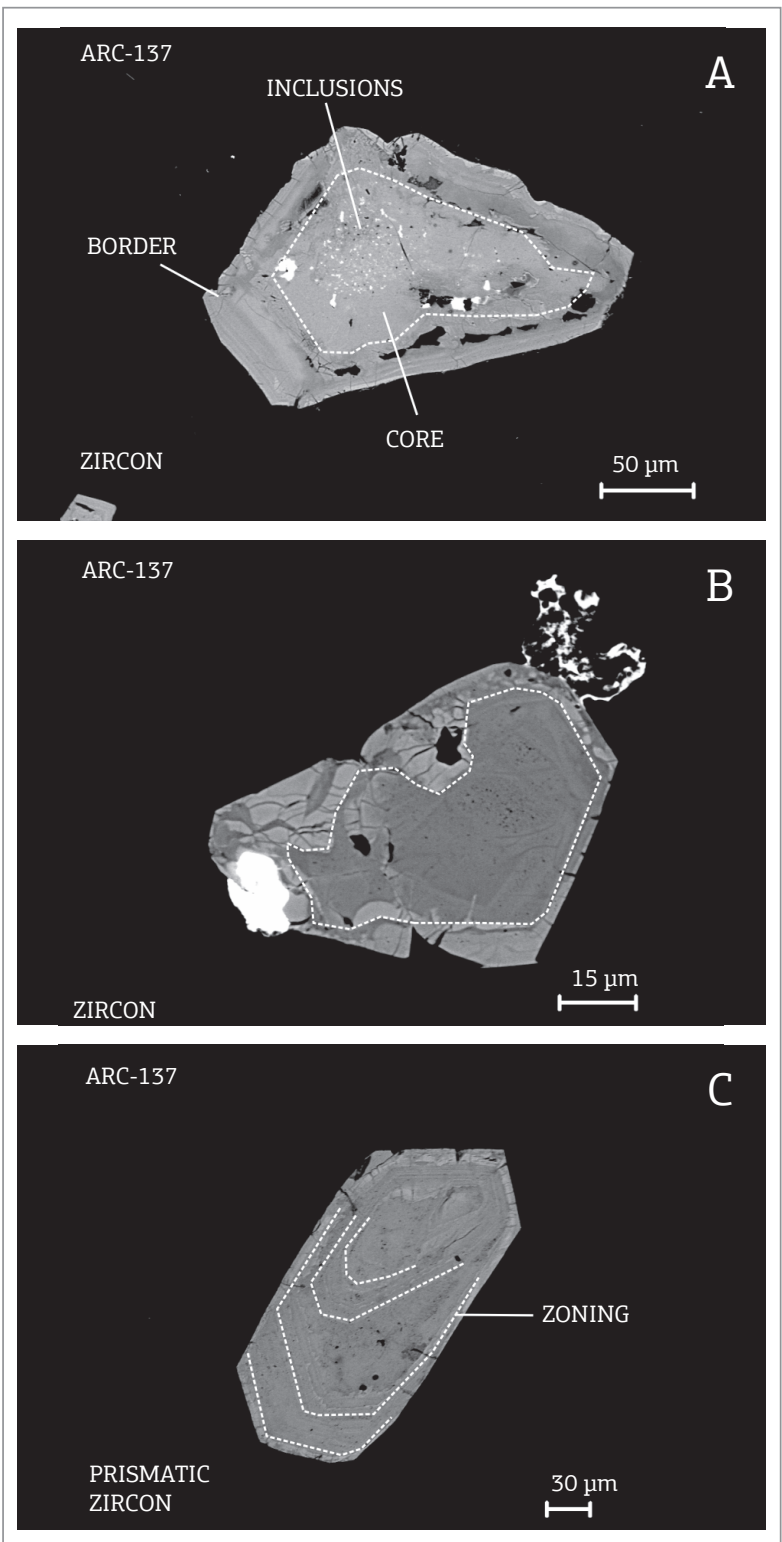

Figure 7. Zircon crystals from the Rio Branco granite. (A and B) strongly metamict crystals; (C) Zoned prismatic crystal. Back scattered electron images obtained with a scanning electron microscope. a single evaporation stage. These ages are not necessarily trustworthy since they could be older ages revealed only at the highest temperatures.

These attempts at dating the granite were inconclusive, probably due to the metamict character of the zircon crystals in the chosen sample. An earlier attempt at dating a different granite sample (ARF-27) encountered the same difficulties, according to unpublished data of A. S. Sardinha. The problem seems to be general, and related to the fact that the granites are very evolved and subject to strong post magmatic modifications. The same is true of very evolved anorogenic granites, and this makes the determination of a precise age, difficult, although in some cases this is possible (cf. Teixeira et al. 2002).

On the other hand, the two ages obtained for grains 2 and 5 of sample ARC-137 are quite close to those obtained $(1.88 \mathrm{Ga})$ for anorogenic granites of Eastern Amazônia (Dall'Agnol et al. 2005). The Paleoproterozoic age together with the other lines of evidence, allow the correlation of the Rio Branco granite with the anorogenic suites of the CP.

\section{ZR/HF RATIOS IN ZIRCON FROM THE RIO BRANCO GRANITE}

$\mathrm{Zr}$ and $\mathrm{Hf}$ are elements with similar ionic radii and electrical charges. Most of their abundance in granites is contained in zircon, and the $\mathrm{Zr} / \mathrm{Hf}$ ratio found in this mineral is regarded as being close to that of the original magma (Owen 1987). Zircon is, therefore, a geochemical tracer mineral. The abundance of Hf in zircon is useful in the identification of the source rocks, the environment of crystallization and the processes of magmatic fractionation, as well as being useful in provenance studies of detrital zircon is sedimentary rocks (Heaman et al. 1990, Uher et al. 1998, Hoskin \& Ireland 2000, Pupin 2000, Wang et al. 2000, Belousova et al. 2002). Specialized granites contain zircon significantly enriched in $\mathrm{Hf}, \mathrm{Y}, \mathrm{Th}, \mathrm{U}$

Table 4. Analytical results of Pb-evaporation on zircon of the syenogranite (ARC-137) of the Rio Branco Granite

\begin{tabular}{|c|c|c|c|c|c|c|c|c|c|c|}
\hline \multicolumn{11}{|c|}{ Rio Branco Granite } \\
\hline Zircon & $\mathrm{T}\left({ }^{\circ} \mathrm{C}\right)$ & Ratios & ${ }^{204} \mathrm{~Pb} /{ }^{206} \mathrm{~Pb}$ & $2 \sigma$ & $\left({ }^{208} \mathrm{~Pb} /{ }^{206} \mathrm{~Pb}\right)^{c}$ & $2 \sigma$ & $\left({ }^{207} \mathrm{~Pb} /{ }^{206} \mathrm{~Pb}\right)^{\mathrm{c}}$ & $2 \sigma$ & Age & $2 \sigma$ \\
\hline ARC137/1 & $1450^{\#}$ & $0 / 36$ & 0.002306 & 0.000348 & 0.44521 & 0.00687 & 0.06661 & 0.00579 & 825.7 & 181.5 \\
\hline \multirow[t]{2}{*}{ ARC137/2 } & 1500 & $4 / 22$ & 0.000000 & 0.000000 & 0.14381 & 0.00279 & 0.11684 & 0.00045 & 1908.7 & 7.0 \\
\hline & $1550^{*}$ & $0 / 6$ & 0.000339 & 0.000400 & 0.11054 & 0.01364 & 0.10462 & 0.00555 & 1708.0 & 97.4 \\
\hline ARC137/3 & $1450^{\#}$ & $0 / 8$ & 0.001107 & 0.000026 & 0.24742 & 0.00235 & 0.06331 & 0.00043 & 718.8 & 14.4 \\
\hline \multirow[t]{2}{*}{ ARC137/4 } & $1450^{\#}$ & $0 / 16$ & 0.000800 & 0.000020 & 0.66911 & 0.00399 & 0.09177 & 0.00225 & 1463.1 & 46.7 \\
\hline & $1500^{*}$ & $0 / 16$ & 0.000167 & 0.000044 & 0.19629 & 0.00168 & 0.11343 & 0.00082 & 1855.3 & 13.0 \\
\hline ARC137/5 & 1500 & $16 / 16$ & 0.000028 & 0.000005 & 0.17136 & 0.00137 & 0.11586 & 0.00102 & 1893.6 & 15.8 \\
\hline ARC137/7 & $1500^{*}$ & $0 / 6$ & 0.000000 & 0.000000 & 0.18900 & 0.02858 & 0.10387 & 0.01032 & 1694.7 & 183.1 \\
\hline ARC137/9 & $1500^{\#}$ & $0 / 32$ & 0.001538 & 0.000679 & 0.37123 & 0.01791 & 0.06998 & 0.01138 & 928.1 & 333.8 \\
\hline
\end{tabular}

${ }^{c}$ ratios ${ }^{207} \mathrm{~Pb} / 206 \mathrm{~Pb}$ and ${ }^{208} \mathrm{~Pb} /{ }^{206} \mathrm{~Pb}$ corrected for common $\mathrm{Pb}$. *Evaporation stage subjectively rejected. 
and $\mathrm{Ca}$, with low $\mathrm{Zr} / \mathrm{Hf}$ ratios, and this fact can be useful as a guide during the initial evaluation of the metallogenetic potential of bodies which could be mineralized in Sn, W, Mo, Ta and Li (Wang et al. 2000, Kempe et al. 2004, Lamarão et al. 2007, 2010).

The zircon crystals of the Rio Branco granite were analyzed for $\mathrm{Hf}$ at the Scanning Electron Microscope Laboratory (LABMEV) of the GI-UFPA using energy dispersive spectrometry (SEM/EDS). The crystals are heavily corroded and altered, having Hf enrichment at the borders. 187 point determinations of border and nuclei revealed variation of $\mathrm{Hf}$ concentrations between 1.8 and $4.8 \%$ with a mean of $3.5 \%$, while $\mathrm{Zr} / \mathrm{Hf}$ ratios vary between 8.6 and 30.5 with a mean of 15.5 .

\section{COMPARISONS BETWEEN THE RIO BRANCO GRANITE AND PALEOPROTEROZOIC A-TYPE GRANITES OF THE CARAJÁS PROVINCE}

The data presented here allow a comparison between the Rio Branco granite and the anorogenic suites of the CP (Dall'Agnol et al. 2005). In common with these suites this granite is isotropic with hypidiomorphic equigranular texture, with no evidence for expressive deformation, and is clearly discordant with the country rocks of Archaean and possibly Paleoproterozoic age. Porphyritic and rapakivi textures are not seen in this granite, but these are not consistent features of the anorogenic suites. The granite has many textural and compositional features found in the more evolved anorogenic suites. In petrographic terms it is similar to the more evolved rocks of the Jamon and Serra dos Carajás Suites, and to the dominant facies of the Velho Guilherme Suite (Fig. 2). It contains biotite, allanite and zircon as primary mafic phases, while post magmatic phases are represented by albite, topaz, fluorite, siderophyllite and sericite - muscovite. In the Jamon Suite the primary accessory minerals are zircon, apatite, magnetite, ilmenite, allanite and titanite (Dall'Agnol et al. 1999, Oliveira et al. 2008, 2009). Fluorite occurs only in the most evolved rocks. Subsolidus processes generally are limited to alteration of plagioclase and mafic minerals. In the Serra dos Carajás Suite the accessory mineral assemblage is similar to that of the Jamon Suite, except that titanite is rare or absent and fluorite is commoner. Tourmaline is occasionally present (Barros et al. 1995, Javier Rios et al. 1995, Ely et al. 2001). In the Velho Guilherme Suite the syenogranitic facies lacks titanite, fluorite is relatively more common, and monazite and xenotime occur sporadically. Siderophyllite may be present on the greisenized topaz.
The MS data and the petrography of opaque minerals for the Rio Branco granite show that it is typical of reduced granites, and this is corroborated by the geochemical data (Fig. 5F). Magalháes et al. (1994) and Dall'Agnol et al. (2005) found relatively high MS values $\left(1.0 \times 10^{-3}\right.$ to $54.7 \times 10^{-3} \mathrm{SI}$ ) with a single mode for Jamon Suite granites. The higher values were found in granodiorite and monzogranite with amphibole, while the lower values occur in biotite leucogranite. SM values for the Serra dos Carajás Suite are moderate $\left(1.0 \times 10^{-3}\right.$ to $\left.5.0 \times 10^{-3} \mathrm{SI}\right)$, while the Velho Guilherme Suite has values in part overlapping the range found for the Serra dos Carajás Suite, but with predominance of lower values of $<1.0 \times 10^{-3}$, principally in syenogranite and alkali-feldspar granite. The frequency polygon and the comparative table of opaque minerals shown in Fig. 8 demonstrate that the Rio Branco granite has a greater affinity with the Velho Guilherme Suite.

Representative data for some of the more evolved granites of the Jamon, Serra dos Carajás and Velho Guilherme Suites (Tab. 3; Fig. 5) show that they are metaluminous to peraluminous (Fig. 5A), are geochemically similar to Phanerozoic intraplate granites (Pearce et al. 1984; Fig. 5B), and have A-type characteristics (Whalen et al. 1987; Fig 5C) of the A2 subtype (Eby 1992; Fig. 5D). They are ferroan granites with $\mathrm{FeOt} /(\mathrm{FeOt}+\mathrm{MgO})>0.8$ (Fig. 5E), and are either reduced (Serra dos Carajás and Velho Guilherme Suites) or oxidized (Jamon Suite). Silica concentrations are $>65 \%$ (Tab. 3), and $\mathrm{Na}_{2} \mathrm{O} / \mathrm{K}_{2} \mathrm{O}$ ratios usually plot between 1.0 and 2.0 , with a progressive increase in the sequence Jamon - Velho Guilherme and Serra dos Carajás (Dall'Agnol et al. 2005).

REE patterns have low $\left(\mathrm{La}_{\mathrm{N}} / \mathrm{Lu}_{\mathrm{N}}\right)$ ratios, and moderate to large negative Eu anomalies (Tab. 3), in general becoming more prominent from the less to the more evolved facies. According to Dall'Agnol et al. (2005), the more prominent negative Eu anomalies are found in specialized syenogranites of the Velho Guilherme Suite and in leucogranites of the Serra dos Carajás Suite. Although the general form of the geochemical characteristics of the Rio Branco granite are similar to those found for the anorogenic granites, its affinity with reduced A-type granites (Fig. 5F; Dall'Agnol \& Oliveira 2007) and its gull-wing REE pattern (Fig. 6) places it closer to the Velho Guilherme Suite.

Zircon compositions also contribute to the comparisons through the $\mathrm{Hf}$ concentrations and the $\mathrm{Zr} / \mathrm{Hf}$ ratios (Lamarão et al. submetido). The mean concentration of Hf (3.5\%) and the mean $\mathrm{Zr} / \mathrm{Hf}$ ratio (15.5) found for the Rio Branco granite are higher and lower, respectively than the means encountered if the oxidized Jamon and moderately reduced Serra dos Carajás Suites ( $\mathrm{Hf}=2.1$ and $3.1 \%$, and 25.0 and 19.0, respectively). The Rio Branco zircons 


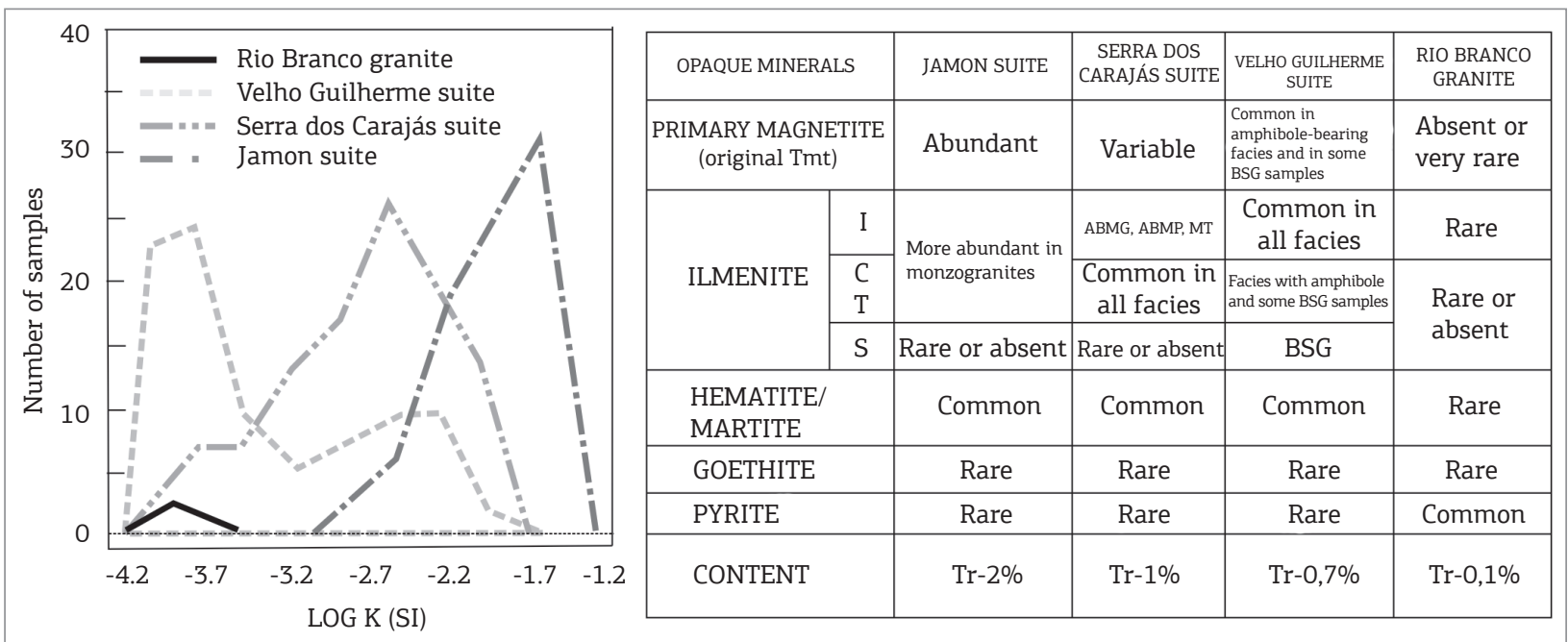

Figure 8. Frequency polygon and comparative table of opaque minerals in the Rio Branco granite and anorogenic suites of the Carajás Province. Data for the latter are based on Magalhães et al. (1994) and Dall'Agnol et al. (2005). Tmt: titanomagnetite; BSG: biotite syenogranite; ABMG: amphibole-biotite monzogranite; ABMP: porphyritic amphibole-biotite monzogranite; MT: modified monzogranite; Ilmenite types: I - individual; C - composite; T trellis; S - sandwich.

are slightly richer in Hf than those from the stanniferous granites of the Velho Guilherme Suite (mean Hf concentration $=3.3 \%$, mean $\mathrm{Zr} / \mathrm{Hf}$ ratio $=16.6)$, although syenogranites of the Bom Jardim granite, one of the members of this suite, has Hf concentrations up to $5.4 \%$, and associated greisens have $\mathrm{Hf}$ concentrations of $5.9 \%$, resulting in $\mathrm{Zr} / \mathrm{Hf}$ ratios of 8.2 and 7.0 (Lamarão et al. submetido).

The characteristics of the Rio Branco granite show that it has potential for tin mineralizations, although so far none have been discovered. It may be that, although it shows favorable characteristics, some at present unknown factor, perhaps the lack of a source rock sufficiently rich in tin which would have allowed its concentration during the magmatic evolution, impeded the formation of mineralizations.

\section{CONCLUSIONS}

The Rio Branco Granite, a Paleoproterozoic stock intrusive on Archean Cruzadão Granite, was partially affected by albitization and greisenization.

- SM data, together with mineralogy (absence of magnetite and titanite) and geochemistry - high $\mathrm{FeOt} /$ $(\mathrm{FeOt}+\mathrm{MgO})$ - show that Rio Branco granite was formed in low oxygen fugacity, below to FMQ tampon. The data suggest similarities with granites of the Velho Guilherme suite or, subordinately, Serra dos Carajás suite. On the other hand, differ from Jamon suite.

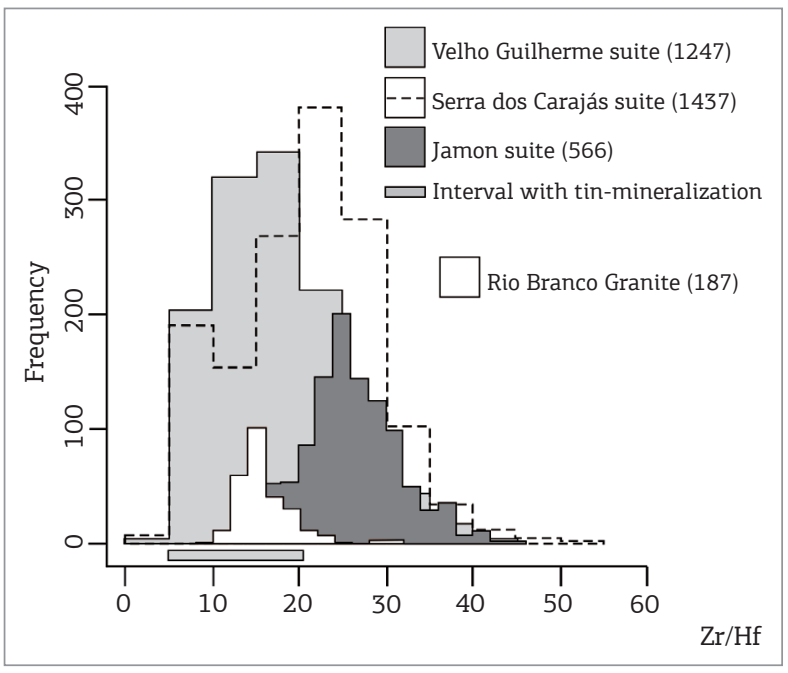

Figure 9. Histogram of $\mathrm{Zr} / \mathrm{Hf}$ ratios in zircon from the Rio Branco Granite compared to those found for zircon in the anorogenic suites. Total numbers of analyses are given in brackets.

The Rio Branco show geochemistry signature of anorogenic, intraplate and A-type granites.

- The geochronology data indicate a Paleoproterozoic age for crystallization of Rio Branco Granite as those of anorogenic suites of Carajás Province.

\section{ACKNOWLEDGMENTS}

We thank colleagues of the Group of Research on Granite Petrology (UFPA) for stimulating discussions about A-type granite; the review Ignez de Pinho 
Guimaráes by help to improve the original manuscript and Ian McReath for help with English translation. The Geosciences Institute of the UFPA for technical support; the National Council for Technological and Scientific Development (CNPq) for conceding Scientific Initiation
(PAS), Doctorate (GRLF) and Research Productivity (RD) grants and other financial support through contract no 484524/07-0. This study is a contribution to the INCT "Amazonia Geosciences" (GEOCIAM; CNPq/MCT/ FAPESPA - Proc. 573733/2008-2).

\section{REFERENCES}

Anderson J.L. \& Morrison J. 2005. Ilmenite, magnetite, and peraluminous Mesoproterozoic anorogenic granites of Laurentia and Baltica. Lithos, 80(1-4):45-60.

Anderson J.L. \& Smith D.R. 1995. The effects of temperature and $\mathrm{fO}_{2}$ on the Al-in-hornblende barometer. American Mineralogist, 80(5-6):549-559

Barros C.E.M., Dall'Agnol R., Vieira E.A.P., Magalhães M.S. 1995. Granito Serra dos Carajás: avaliação do potencial metalogenético para estanho com base em estudos da borda oeste do corpo. Boletim Museu Paraense Emílio Goeldi, série Ciências da Terra, 93-123.

Belousova E.A., Griffin W.L., O’Reilly S.Y. Fisher N. 2002. Igneous zircon: trace element composition as an indicator of source rock type. Contributions to Mineralogy and Petrology, 143(5):602-622.

Dall'Agnol R., Oliveira D.C. 2007. Oxidized, magnetite-series, rapakivitype granites of Carajás, Brazil: implications for classification and petrogenesis of A-type granites. Lithos, 93(3-4):215-233.

Dall'Agnol R., Oliveira M.A., Almeida J.A.C., Althoff F.J, Leite A.A.S., Oliveira D.C., et al. 2006. Archean and Paleoproterozoic granitoids of the Carajás Metallogenic Province, eastern Amazonian Craton. In: Dall'Agnol R., Rosa-Costa L.T. and Klein E.L. (eds.) Symposium on magmatism, crustal evolution, and metallogenesis of the Amazonian Craton. Abstracts Volume and Field Trip Guide. Belém, PRONEX-UFPA-SBGNO, 99-150.

Dall'Agnol R., Teixeira N.P., Rämö O.T., Moura C.A.V., Macambira M.J.B., Oliveira D.C.O. 2005. Petrogenesis of the Paleoproterozoic rapakivi A-type granites of the Archean Carajás metallogenetic province, Brazil. Lithos, 80(1-4):101-129.

Dall'Agnol R., Ramö O.T., Magalhães M.S., Macambira M.J.B. 1999. Petrology of the anorogenic, oxidised Jamon and Musa Granites, Amazonian Craton: implications for the genesis of Proterozoic A-type Granites. Lithos, 46(3):431-462.

Dall'Agnol R., Souza Z.S., Althoff F.J., Barros C.E.M., Leite A.A.S., Jorge João X.S. 1997. General aspects of the granitogenesis of the Carajás metallogenic province. In: Superintendência de Geologia e Recursos Minerais, SBG, Intern. Symp. on Gran. and Associated Mineralizations, 2. Salvador, Atas, p. 135-161.

Dall'Agnol R., Teixeira N.P., Magalhães M.S. 1993. Diagnostic features of tin-specialized anorogenic granites of the Amazonian Region. Anais da Academia Brasileira de Ciências, 65:33-50.

Eby G.N. 1992. Chemical subdivision of the A-type granitoids: petrogenetic and tectonic implications. Geology, 20(7):641-644.

Ely F.M., Althoff F.J., Lindenmayer Z.G. 2001. Petrografia e Geoquímica dos Granitóides dos Depósitos Gameleira e Pojuca, Serra dos Carajás, PA. In: Simpósio de Geologia da Amazônia, 7. Boletim de Resumos Expandidos, CD-room.

Evensen N.M., Hamilton P.J., O'nions R.K. 1978. Rare-earth abundance in chondritic meteorites. Geochimica et Cosmochimica Acta. 42(8):1199-1212.

Feio G.R.L., Dall'Agnol R., Dantas E.L. Macambira M.J.B., Santos J.O.S., Althoff F.., et al. 2013. Archean granitoid magmatism in the Canaã dos
Carajás area: implications for crustal evolution of the Carajás province, Amazonian craton, Brazil. Precambrian Research. DOI: 10.1016/j. precamres.2012.04.007. Acesso em: 12/12/2012.

Ferreira A.T.R. 2009. Petrografia, Geoquímica e Geocronologia dos diques da área de Bannach, Terreno Granito-Greenstone de Rio Maria, SE do Pará. Trabalho de Conclusão de curso, Instituto de Geociências, Universidade Federal do Pará, Belém.

Frost B.R., Barnes C., Collins W., Arculus R., Ellis D., Frost C. 2001. A chemical classification for granitic rocks. Journal of Petrology, 42(11):2033-2048

Gastal M.C.P. 1987. Petrologia do Maciço Granítico Musa, Sudeste do Pará. Dissertação de Mestrado em Geologia e Geoquímica, Instituto de Geociências, Universidade Federal do Pará, Belém. 316 p.

Gaudette H.E., Lafon J.M., Moura C.A.V., Sheller T. 1998. Comparison of single filament $\mathrm{Pb}$ evaporation/ionization zircon age with conventional U-Pb results: examples from the Precambrian of Brazil. Journal of South American Earth Sciences, 11(4):351-363.

Haapala, I. 1997. Magmatic and post-magmatic processes in tinmineralized granites: topaz bearing leucogranite in Eurajoki Rapakivi Granite stock. Finland. Journal of Petrology, 38(12):1645-1649.

Heaman L.M., Bowins R., Crocket J. 1990. The chemical composition of igneous zircon suites: Implications for geochemical tracer studies. Geochimica et Cosmochimica Acta, 54(6):1597-1607.

Hoskin P.W.O. \& Ireland T.R. 2000. Rare earth element chemistry of zircon and its use as a provenance indicator. Geology, 28(7):627-630.

Huhn S.R.B., Santos A.B.S., Amaral A.F., Ledsham E.J., Gouveia J.L., Martins L.B.P., Montalvão R.M.G., Costa V.G. 1988. O terreno granitogreenstone da região de Rio Maria - sul do Pará. In: Congr. Bras. Geol., 35., Belém, Anais, 3:1438-1453.

Javier Rios, F. Villas, R.N., Dall'Agnol, R. 1995. O Granito Serra dos Carajás: I. Fácies petrográficas e evolução petrológica do setor norte. Revista Brasileira de Geociências, 25(1):20-31.

Kempe U., Gruner T., Renno A.D., Wolf D., René M. 2004. Discussion on Wang et al. (2000) "Chemistry of Hf-rich zircons from the Laoshan I- and A-type granites, Eastern China". Mineralogical Magazine, 64(5):867-877

Kober B. 1986. Whole-grain evaporation for ${ }^{207} \mathrm{~Pb} / 206 \mathrm{~Pb}$ age investigations on single zircons using a Double filament source. Contributions to Mineralogy and Petrology, 93(4):482-490.

Kober B. 1987. Single-zircon evaporation combined with $\mathrm{Pb}+$ emitter bedding for ${ }^{207} \mathrm{~Pb} / 206 \mathrm{~Pb}$ investigations using thermal ion mass spectrometry, and implications for zirconology. Contributions to Mineralogy and Petrology, 96(1):63-71

Kretz R. 1983. Symbols for rock-forming minerals. American Mineralogist, 68:277-279.

Lamarão C.N., Dall'Agnol R., Soledade G.L., Silva J.S. 2007. Variações composicionais de zircão em granitos anorogênicos proterozóicos do Cráton Amazônico: implicações metalogenéticas. Revista Brasileira de Geociências, 37(4):693-704. 
Lamarão C.N., Dall'Agnol R., Silva J.S., Soledade G.L. 2010. Morphological and compositional variation in zircons of tinspecialized Paleoproterozoic A-type granites of the Amazonian craton: Metallogenic implications. In: Tapani Ramo O., Lukkari S., Heinonen A. (eds.) International Conference on A-type granites and related rocks though time (IGCP-510), Helsinki-Finland. Helsinki University-Department of Geosciences and Geography, Helsinki University Print, Abstract Volume.

Lamarão C.N., Silva J.S., Borges, R.M.K., Dall'Agnol R. (submetido). Variação Morfológica e Composicional de Zircão e suas Implicações Metalogenéticas: o exemplo das Suítes Jamon, Velho Guilherme e Serra dos Carajás, Cráton Amazônico. Revista Brasileira de Geociências.

Loiselle M.C., Wones D.R. 1979. Characteristics and origin of anorogenic granites. Geological Society of America, abstracts with programs, 11:468.

Magalhães M.S., Dall'Agnol R., Sauck W.A., Luiz J.G. 1994. Suscetibilidade magnética: um indicador da evolução petrológica de granitóides da Amazônia. Revista Brasileira de Geociências, 24(3):139-149.

Oliveira D.C., Dall'Agnol R., Corrêa da Silva J.B., Almeida J.A.C. 2008. Gravimetric, radiometric, and magnetic susceptibility study of the Paleoproterozoic Redenção and Bannach plutons: implications for architecture and zoning of A-type granites. Journal of South American Earth Sciences, 25(1):100-115

Oliveira D.C., Dall'Agnol, R., Barros, C.E.M., Oliveira, M.A. 2009. Geology, Geochemistry and Magmatic Evolution of the Paleoproterozoic, Anorogenic Oxidized A-type Redenção Granite of the Jamon Suite, Eastern Amazonian Craton, Brazil. The Canadian Mineralogist, 47(6):1441-1468.

Owen M.R. 1987. Hafnium content of detrital zircons: A new tool for provenance study. Journal of Sedimentary Petrology, 7:24-830.

Paiva Jr. A.L. Lamarão, C.N., Lima, P.H.A. 2011. Geologia, Petrografia e Geoquímica do Batólito Seringa, Província Carajás, SSE do Pará. Revista Brasileira de Geociências, 41(2):185-202.

Pearce J.A., Harris N.B.W., Tindle A.G. 1984. Trace element discrimination diagrams for the tectonic interpretation of granitic rocks. Journal of Petrology, 25(4):956-983

Pupin J.P. 2000. Granite genesis related to geodynamics from Hf-Y in zircon. Transactions of the Royal Society of Edinburgh: Earth and Environmental Science, 91(1-2):245-256.

Ramberg H. 1962. Intergranular precipitation of albite formed by unmixing of alkali feldspar. Neues Jahrbuchfür Mineralogie Abhandlungen, 98:14-34

Santos J.O.S., Hartmann L.A., Gaudette H.E., Groves D.I., McNaughton N.J., Fletcher I.R. 2000. A new understanding of the provinces of the Amazon Craton based on integration of field mapping and $\mathrm{U}-\mathrm{Pb}$ and Sm-Nd geochronology. Gondwana Research, 3(4):453-488.

Sardinha A.S. 2005. Geocronologia das séries magmáticas e evolução crustal da região de Canaã dos Carajás, Província Mineral de Carajás-PA. Texto do exame de Qualificação. Doutorado em Geologia e Geoquímica, Instituto de Geociências, Universidade Federal do Pará, Belém. 100 p.

Shand S.J. 1950. Eruptive rocks their genesis, composition classification and their relation to ore deposit. 4. ed., London, Thomas Murbyand, $488 \mathrm{p}$.

Silva Jr. R.O., Dall'Agnol R., Oliveira E.P. 1999. Geologia, petrografia e geoquímica dos diques proterozóicos da região de Rio Maria, sudeste do Pará. Geochimica Brasiliensis, 13(2):161-183.

Smith J.V., Brown, W.L. 1988. Feldspar minerals. 2. ed., Berlin, Springer-Verlag, $828 \mathrm{p}$
Smith, J.V. 1974. Feldspar Minerals. II. Chemical and textural properties. Berlin, Spriger-Verlag, $670 \mathrm{p}$.

Soares J.E.B. 2002. Geologia, petrografia e geoquímica das rochas granitóides arqueanas da região de Serra Dourada, Canaã dos CarajásPA. Texto de Qualificação. Doutorado em Geologia e Geoquímica Instituto de Geociências, Universidade Federal do Pará, Belém.70 p.

Souza S. Z., Dall'Agnol R., Althoff F. J., Leite A.A.S., Barros C.E.M. 1996. Carajás mineral province: geological, geochronological and tectonic constrasts on the Archean evolution of the Rio Maria Granite-Greenstone Terrain and the Carajás block. In: Symposium on Archean Terranes of South America Platform, Brasília, Extended abstracts. SBG. p. 31-32.

Souza Z.S., Medeiros H., Althoff F.J., Dall'Agnol R. 1990. Geologia do terreno granito - greenstone arqueano da região de Rio Maria, sudeste do Pará. In: $36^{\circ}$ Congresso Brasileiro de Geologia, Natal. Anais, Natal : Sociedade Brasileira de Geologia, Núcleo Nordeste, 6:2913-2928

StaceyJ.S., Kramers J.D. 1975. Approximation of terrestrial lead isotope evolution by a two-stage model. Earth and Planetary Science Letters, 26(2):207-221.

Streckeisen A.L. 1976. To each plutonic rock its proper name. EarthScience Reviews, 12(1):1-33.

Tassinari C.C.G., Macambira M., 2004. A evolução tectônica do Craton Amazônico. In: Mantesso-Neto V., Bartorelli A., Carneiro C.D.R., Brito Neves B.B. (eds.). Geologia do Continente Sul Americano: Evolução da obra de Fernando Flávio Marques Almeida. São Paulo, p. 471-486.

Taylor R.P. \& Fryer B.J. 1983. Rare earth lithogeochemistry of granitoid mineral deposits. Bulletin of the Canadian Institute of Mining and Metallurgy, 76:74-84.

Teixeira N.P. 1999. Contribuição ao estudo das rochas granitóides e mineralizações associadas da Suite Intrusiva Velho Guilherme, Província Estanífera do Sul do Pará. Tese de Doutorado, Instituto de Geociências, Universidade de São Paulo, São Paulo. 508 p.

Teixeira N.P., Bettencourt J.S., Moura C.A.V., Dall'Agnol R. Macambira E.M.B. 2002. Archean crustal sources for Paleoproterozoic tin-mineralized granites in the Carajás Province, SSE Pará, Brasil: $\mathrm{Pb}-\mathrm{Pb}$ geochronology and Nd isotope geochemistry. Precambrian Research, 119(1-4): 257-275.

Teixeira N.P., Bettencourt J.S., Dall'Agnol R., Moura C.A.V., Fernandes C.M.D., Pinho S.C.C.P. 2005. Geoquímica dos granitos paleoproterozóicos da Suíte granítica Velho Guilherme, Província Estanífera do Sul do Pará. Revista Brasileira de Geociências, 35(2):217-226.

Teixeira W., Tassinari C.C.G., Cordani U.G., Kawashita K. 1989. A review of the geochronology of the Amazonian Craton: tectonic implications. Precambrian Research, 42(3-4):213-227.

Uher P., Breiter K., Klecka M., Pivec E. 1998. Zircon in highly evolved Hercynian Homolka Granite, Moldanubian Zone, Czech Republich: indicator of magma source and petrogenesis. Geologica Carpathica, 49(3):151-160

Vasquez L.V., Rosa-Costa L.R., Silva C.G., Ricci P.F., Barbosa J.O., Klein E.L., et al. 2008. Geologia e Recursos Minerais do Estado do Pará: Sistema de Informações Geográficas - SIG: texto explicativo dos mapas Geológico e Tectônico e de Recursos Minerais do Estado do Pará, 328 p.

Wang R.C., Zhao G.T., Lu J.J., Chen X.M., Xu S.J., Wang D.Z. 2000. Chemistry of Hf zircons from the Laoshan I- and A-type granites, Eastern China. Mineralogical Magazine, 64(5):867-877.

Whalen J.W., Currie K.L., Chappel B.W. 1987. A-type granites: geochemical characteristics, discrimination and petrogenesis Contributions to Mineralogical Petrology, 95(4):407-419.

Arquivo digital disponível on-line no site www.sbgeo.org.br 